\title{
Effects of dietary propolis and vitamin E on growth performance and antioxidant status in blood of juvenile Rainbow trout, Oncorhynchus mykiss (Teleostei: Salmoniformes) under different flow rates
}

\author{
Gülüzar Tuna Kelestemur ${ }^{1}$, Pinar Tatli Seven ${ }^{2} \&$ Seval Yilmaz ${ }^{3}$ \\ ${ }^{1}$ Corresponding author. Universit of Firat, Faculty of Fisheries, Department of Aquaculture, Elazig, Turkey. \\ E-mail: gkelestemur@firat.edu.tr \\ 2 Universit of Firat, Faculty of Veterinary, Department of Animal Nutrition and Nutritional Diseases, Elazig, Turkey. \\ ${ }^{3}$ Universit of Firat, Faculty of Veterinary, Department of Biochemistry, Elazig, Turkey.
}

\begin{abstract}
The present study investigated the effects of propolis and vitamin E supplementation in diets of juvenil rainbow trout subjected to two different flow rates with or without flow stress ( 0.9 and $2.1 \mathrm{l} / \mathrm{min}$, respectively) on final weigth (FW), condition factor (CF), feed conservation ratio (FCR), protein efficiency ratio (PER) and vitamin $A, C$ and $E$ concentrations and malondialdehyde (MDA) levels in serum as well as plasma superoxide dismutase (SOD) activity. The experimental groups were as follows: group C was fed a basal diet, group P10 was fed a basal diet supplemented with $10 \mathrm{~g}$ propolis $/ \mathrm{kg}$, group P30 was fed a basal diet supplemented with $30 \mathrm{~g}$ propolis $/ \mathrm{kg}$, group E60 was fed a basal diet supplemented with 60 $\mathrm{mg}$ vitamin $\mathrm{E} / \mathrm{kg}$. CF and PER were not different among all diets groups for both flow rate treatments $(p>0.05)$. The FCR improved in P10, P30 and E60 diet groups compared to $C$ diet group at $2.1 \mathrm{l} / \mathrm{min}$ flow rate $(\mathrm{p}<0.05)$. The FCR of E60 and P30 were found to be better than $C$ and P10 diet groups at $0.9 \mathrm{I} / \mathrm{min}$ flow rate $(p<0.05)$. Vitamin $E$ and propolis supplementations did not affect vitamin A concentration of serum for either flow rate $(p>0.05)$. Fish fed with diet E60 had higher serum vitamin E concentration than other groups $(p<0.05)$. Serum Vitamin $C$ concentration was only affected by the propolis supplemented diets. MDA level of $\mathrm{E} 60$ group was found significantly lower comperad to other groups for both flow rate $(p<0.05)$. Plasma SOD activity significantly decreased in the E60 group compared to other groups at $2.1 \mathrm{I} / \mathrm{min}$ flow rate $(p<0.05)$. But plasma SOD activity was not different among all diets groups at $0.9 \mathrm{I} / \mathrm{min}$ flow rate $(p>0.05)$.

KEY WORDS. Lipid peroxidation; rainbow trout; superoxide dismutase; vitamin E.
\end{abstract}

Reductions of oxygen concentration in water have resulted in significant changes in antioxidant defense system in teleosts. Generation of reactive oxidative species (ROS) increases under hypoxic conditions (Lushchak \& Bangnyukova 2006, MARKovic et al. 2002). ROS can impair lipids, proteins, carbohydrates and nucleotides which are important parts of cellular constituents, including membranes, enzymes and DNA. Radical damage can be significant because it can proceed as a chain reaction (CHEN \& PAN 1996, WEJIL et al. 1997). These radicals can damage cell membranes by inducing lipid peroxidation of polyunsaturated fatty acids in the cell membrane (FANG et al. 2002, Stephan et al. 1995). Malondialdehyde is the final product of lipid peroxidation. The concentration of MDA is the direct evidence of toxic processes caused by free radicals (TALAS \& Gülhan 2009, Tatli Seven et al. 2009, Selamoglu Talas et al. 2008). Like other vertebrates, fish possess an antioxidant system both enzymatic and non-enzymatic. The more relevant antioxidant enzymes consist of glutathione reductase, superoxide dismutase, catalase and peroxidase, and non-enzymatic defenses include vitamin E, vitamin C, vitamin A, coenzyme Q, flavonoids (GÜLÇIN et al. 2009, PuAngKaEw et al. 2005).
Living organisms are able to adapt to oxidative stress by inducing the synthesis of antioxidant enzymes and damage removal/repair enzymes (MARTínez-Álvarez et al. 2005, GABRYELAK 1983). SOD is an important antioxidant enzyme to inhibit oxyradical formation and is usually used as a biomarker to indicate oxidative stres. Superoxide dismutase, a cytosolic enzyme that is specific for scavenging superoxide radicals, is involved in protective mechanisms within tissue injury following oxidative process and phagocytosis (Jia et al. 2010, Lopez-Torres et al. 1993). The higher the SOD value is, the more superoxide radicals need to be reacted. Four types of SOD have been identified on the basis of their metal cofactors and distribution. Manganese is present in mitochondrial SOD, whereas cytosolic SODs contain $\mathrm{Cu}$ and $\mathrm{Zn}$. The copper zinc form (Cu/ZnSOD) is most common with a primary distribution in the cytoplasm of eukaryotic cells (Hidalgo et al. 2002, ANDRAde et al. 2007).

On the other hand, some nonenzymatic antioxidants are micronutrients which derive directly from the diet, while others must be appropriately supplied in order to maintain the necessary concentrations in the body (Hidalgo et al. 2002, SEven et al. 2010). Antioxidant vitamins (mainly A, C and E vitamins) 
also directly scavenge ROS and upregulate the activities of antioxidant enzymes. Vitamin A (retinol and some retinol metabolites) and pro-vitamin A carotenoids (mainly beta-carotene) are well known dietary antioxidants, respectively, derived from animal and plant sources (Quiles et al. 2002). Vitamins C (ascorbic acid) and $\mathrm{E}$ ( $\alpha$-tocopherol) are among the most important nutrients influencing the organism immune system and their supply can reduce fish mortality and improve performance. Vitamin $\mathrm{C}$ is a potent antioxidant that offers protection against oxidative damage to various fish tissues. Vitamin $\mathrm{E}$ has proven beneficial in protecting cellular membranes against oxidation, increases the resistance to stress (CHOI et al. 2004, FANG et al. 2002, HenRIQue et al. 1998).

Propolis is a resinous material collected by bees from bud and exudates of plants, which is mixed with products of their salivary glands and wax. Its color varies from green, red to dark brown. Propolis has been used in folk medicine since ancient times. Propolis has attracted researchers' interest in the last decades because of several biological and pharmacological properties, such as immunomodulatory, antitumor, antimicrobial, anti-inflammatory, and antioxidant, among others (TALAS \& GulHan 2009). The anti-oxidative, cytostatic, anti-mutagenic and immunomodulatory properties of propolis are based on its rich, flavonoid, phenolic acid and terpenoid contents (Кімото et al. 1999, РRYTZYк et al. 2003, WANG et al. 2004).

In recent years, there has been a great deal of studies carried out on propolis metabolism, but none of these studies investigated effect of the propolis and vitamin $\mathrm{E}$ on biochemical parameters of juvenile rainbow trout under hypoxic stress. Thus, this study aimed to investigate the effects of vitamin E and propolis on growth performance and oxidative-antioxidative system in stressed and unstressed rainbow trout.

\section{MATERIAL AND METHODS}

Rainbow trout, Oncorhynchus mykiss (Walbaum, 1792), produced at the Çirçir Hatchery (Elazig, Turkey) were transferred to Keban Dam Lake General Directorate of State Hydraulic Works Laboratory. After the acclimation, fish were selected and randomly stoced. Fish (initial weight and length, $42.27 \pm 2.14$ g, $14.23 \pm 0.71 \mathrm{~cm}$, respectively) were distributed into 24 fiberglass rectangular $(200 \mathrm{~cm} \times 40 \mathrm{~cm} \times 40 \mathrm{~cm})$ tanks with a $4 \times 2 \times 3$ experimental design (4 diets group $\times 2$ flow rates $\times 3$ replicate groups) with a density of 20 juvenile rainbow trout per tank. Experiments were conducted in a tank, supplied with well water two different flow rates, 2.1 and $0.9 \mathrm{l} / \mathrm{min}$. The flow rates that were determined for the low and optimal flow rate groups were stabilized through the use of the water inflow control valves (Tuna Kelestemur \& Ozdemir 2010).

The investigation was initiated after the levels of dissolved oxygen were attained at $7.6 \mathrm{mg} / \mathrm{l}$ at a flow rate of $2.1 \mathrm{l} / \mathrm{min}$ and $4.5 \mathrm{mg} / \mathrm{l}$ at a flow rate of $0.9 \mathrm{l} / \mathrm{min}$. The $\mathrm{pH}$ of the water in the tanks where the fish were situated was determined by a por- table Checker brand $\mathrm{pH}$ meter and the dissolved oxygen and the temperature values were recorded through the use of a portable YSI 55 Model 51/12 oxygen probe throughout the duration of the research. Temperature ranged from 8.8 to $9.4^{\circ} \mathrm{C}$ and $\mathrm{pH}$ ranged from 8.4 to 8.6 during the experimental period. Shown in Table I, some other physical and chemical values of used water. Before the fish were anesthesia ( $15 \mathrm{mg} / \mathrm{l}$ Quinaldin), these body weights were measured one every two weeks.

Table I. The values of physical and chemical properties of water used in this study.

\begin{tabular}{lc}
\hline \multicolumn{1}{c}{ Parameters } & Values \\
\hline Turbidity & 0.2 \\
Conductivity $(\mathrm{mS} / \mathrm{cm})$ & 235 \\
Total alkalinity $(\mathrm{mg} / \mathrm{l})$ & 77.3 \\
Total dissolved carbon dioxide $(\mathrm{ppm})$ & 13.07 \\
Hydrogen sulfur $(\mathrm{ppm})$ & 0.03 \\
Sulfat $(\mathrm{mg} / \mathrm{l})$ & 37.6 \\
Total solids $(\mathrm{mg} / \mathrm{l})$ & 10 \\
Nitrate $(\mathrm{mg} / \mathrm{l})$ & 0.7 \\
Total hardness $(\mathrm{CaCO})(\mathrm{mg} / \mathrm{l})$ & 88.24 \\
Fosfate $(\mathrm{mg} / \mathrm{l})$ & 0.05 \\
Clorur $(\mathrm{mg} / \mathrm{l})$ & 0.001 \\
Ammonium $(\mathrm{mg} / \mathrm{l})$ & 0.001 \\
\hline
\end{tabular}

Composition of the basal diet is shown in Table II. The basal composition of the experimental diets was based on National Research Council (NCR 1993).

Experimental diets supplemented with $10,30 \mathrm{~g} / \mathrm{kg}$ propolis (respectively; P10, P30), $60 \mathrm{mg} / \mathrm{kg}$ vitamin E (Rovimix E50 adsorbate; min.\%50 dl- $\alpha$-tocopherly acetate) (E60) dry diet and basal diet (C) (not supplemented diet of propolis and vitamin E) were prepared. Vitamin $\mathrm{E}$ is subsequently added to the E60 diets, no supplemental vitamin $\mathrm{E}$ was added to the basal (C), P10 and P30 diets. During two week conditioning period, fish were fed basal diet to adjust to the experimental conditions and to deplete body reserves of vitamin $\mathrm{E}$.

The prepared pellets were dried in 24 hours at $45^{\circ} \mathrm{C}$ and during the trial were stored at $+4^{\circ} \mathrm{C}$. Dry matter $\left(105^{\circ} \mathrm{C}\right.$, overnight), ash $\left(550^{\circ} \mathrm{C}\right.$, overnight), crude protein (nitrogen $\left.\times 6.25\right)$, ether extract, crude fibre of diets were analyzed by methods of AOAC (1990). Fish were fed three times per day at a feeding rate of $3 \%$ body weight per day for 12 weeks.

Propolis samples were collected from Elazig province (Eastern Anatolia, Turkey). Handcollected propolis samples were kept dried in the dark until processing. Propolis samples were extracted for a week with $100 \mathrm{ml}$ of $70 \%$ ethanol, at room temperature to obtain the extract (BLONSKA et al. 2004). After filtration, the extract was evaporated by using a vacuum evaporator at $50^{\circ} \mathrm{C}$. Afterwards the extract was used in the experiment. Gas chroma- 
Table II. Composition and proximate analysis of the experimental basal diet.

\begin{tabular}{lc}
\hline Ingredient & $\%$ \\
\hline Fish (anchovy) meal & 50.00 \\
Soybean meal & 17.20 \\
Wheat flour & 21.80 \\
Sunflower oil & 8.50 \\
Antioxidant $^{\text {a }}$ & 0.50 \\
Vitamin premix $^{\text {b }}$ & 1.00 \\
Mineral premix $^{c}$ & 1.00 \\
\hline Total & 100.00 \\
\hline Proximate composition & $\%$ \\
\hline Dry matter & 80.35 \\
Crude protein & 44.48 \\
Crude fat & 8.02 \\
Crude fibre & 4.12 \\
Crude ash & 13.10 \\
\hline
\end{tabular}

a Antioxidant (mg/kg dry diet): Butilen Hydroxytoluene (BHT); $125.000 \mathrm{mg} / \mathrm{kg}$.

b Vitamin premix (IU or $\mathrm{mg} / \mathrm{kg}$ dry diet): Menadion 3.000, Riboflavin 6.000, Pridocxin 5.000, Cobalamine 15,Ascorbik acid 150.000, Niasin 25.000, Biotin 40, Folic acid 1.000, Colin Chloride 300, Calciyum D-pantothenat 8.000, Retinol 12.000.000, Calsiferol 2.000.000 IU.

c Mineral premix (mg/kg dry diet): Mn 80.000, Fe 35.000, Zn 50.000, Cu 5.000, I 2.000, Co 400, Se 150.

tography-mass spectrometry analyses were carried out to detect the main components of propolis by an Agilent GC 6890 gas chromatograph, coupled to an Agilent MSD 5973 mass detector under electron impact ionization mode. The gas chromatography column was Zebron (ZB-1) methyl polysiloxane $(30 \mathrm{ml} \times$ $0.25 \mathrm{~mm} 10 \times 0.25 \mathrm{mdf}$ ). Helium was used as carrier gas at a flow rate of $10 \mathrm{ml} / \mathrm{min}$. Propolis samples were analyzed with the column held initially at $100^{\circ} \mathrm{C}$ for five minutes and then increased to $150^{\circ} \mathrm{C}$ and kept at $150^{\circ} \mathrm{C}$ for two minutes. Finally, the temperature of the sample was raised to $280^{\circ} \mathrm{C}$ with a ramp rate of $2^{\circ} \mathrm{C} / \mathrm{min}$, and it was kept constant at $280^{\circ} \mathrm{C}$ for 60 minutes. The injection was performed in split mode at $250^{\circ} \mathrm{C}$ and the peaks were identified by computer searches in commercial reference libraries. The main components of propolis samples were determined by considering their areas as percentage of the total ion current. The main compounds of propolis samples are identified and listed in Table III.

Finally of the experements, blood was obtained from the caudal vasculature of ten fish per tank after the anesthetic process. Serum samples were collected from tubes blood by centrifugation. Plasma samples were collected from heparinized blood by centrifugation. Serum and plasma was then separated and stored at $-20^{\circ} \mathrm{C}$ until analyzed (Atamanalp \& BayiR 2003).
Table III. Chemical composition assessed by GC-MS of propolis. ${ }^{1}$

\begin{tabular}{rllc}
\hline \multicolumn{1}{c}{ RT } & \multicolumn{1}{c}{ Contents } & TIC (\%) \\
\hline 52.49 & & Chrysin & 5.33 \\
53.67 & Flavonoids & Acacetin & 3.02 \\
51.66 & & Naringenin & 2.67 \\
\hline 55.49 & & Decanoic acid & 0.28 \\
46.93 & & Octadecanoic acid & 0.39 \\
21.00 & Aliphatic acids & Tetradecanoic acid & 0.40 \\
51.22 & & Undecanoic acid & 0.79 \\
7.18 & & Butanedioic acid & 0.77 \\
\hline 26.93 & & Ferulic acid & 0.43 \\
24.80 & Aromatic acids & Cinnamic acid & 0.41 \\
31.20 & & Palmitoleic acid & 0.51 \\
\hline 34.92 & \multirow{2}{*}{ Esters } & 4,3-Acetyloxycaffeate & 0.52 \\
36.33 & & Caffeic acid TMS ester & 0.39 \\
\hline 11.43 & & 1-Propen-1-thiol & 4.51 \\
7.18 & Alcohol, & 1-Siklohekzen-1-methanol & 4.64 \\
28.93 & terpene and & Farnesol & 20.64 \\
14.97 & quinone & Limonen dioxide & 0.78 \\
6.87 & & Glycerole & 1.04 \\
\hline 11.43 & & 1H-sikolpentafuran & 3.17 \\
53.43 & \multirow{2}{*}{ Others } & 3-Hexane & 1.61 \\
56.46 & & Heptane & 0.02 \\
42.17 & & 1,3-Bis-5-propyl benzene & 0.55 \\
\hline RT:Retenton time; TiC: &
\end{tabular}

RT: Retention time; TIC: Total ion concentration.

${ }^{1}$ The ion current generated depends on the characteristics of the compound concerned and it is not a true quantitation.

Serum samples were transferred into polyethylene tubes and $0.5 \mathrm{ml} \mathrm{HClO}_{4}(0.5 \mathrm{M}), 4.5 \mathrm{ml}$ distilled water and $100 \mathrm{ml}$ 500 ppm 2(6)-di-tert-butyl-p-cresol (BTH) was added to the tubes. Then, the samples were centrifuged at $3500 \mathrm{rpm}$ for 5 min and the supernatants were injected into the HPLC. The mobile phase was $30 \mathrm{mM} \mathrm{KH} \mathrm{PO}_{4}$-methanol $(82.5+17.5$, v/v\%, $\mathrm{pH}$ 3.6) mixture and the flow rate was $1.2 \mathrm{ml} \mathrm{min}^{-1}$. The chromatograms were detected at $250 \mathrm{~nm}$ and the injection volume was $20 \mathrm{ml}$ (Miller et al. 1984).

Serum samples were transferred into polyethylene tubes and $2 \mathrm{ml}$ of ethanol was added to the tubes. Following the addition of $0.3 \mathrm{ml} \mathrm{n}$-hexane that is required for the vitamin extractions into the tubes, they were centrifuged. This step was repeated for two times. N-hexane in the tubes was evaporated using nitrogen. Then the residues were dissolved in the mobile phase (methanol: acetonitrile: chloroform; 47:42:11,v/v/v). The chromatographs were monitored at 326 and $296 \mathrm{~nm}$ for vitamins A and E, respectively and the injection volume was set to $50 \mathrm{ml}$. Techsphere ODS-2 packed column ( $5 \mathrm{~mm}$ particle, $250 \times$ 4.6 ID) was used and the flow rate was $1.0 \mathrm{ml} \mathrm{min}^{-1}$ (KaratepE 2004). 
Superoxide dismutase was assayed by the method reported by McCord \& Fridovich (1969). The SOD activity was measured using the RANSOD kit. The role of SOD is to accelerate the dismutation of the toxic superoxide radical, produced during oxidative energy processes, to hydrogen peroxide and molecular oxygen. The reaction was based on its inhibitory effect on the rate of superoxide-dependent reduction of nitroblue tetrazolium (NBT) by xanthine-xanthine oxidase that was monitored at $505 \mathrm{~nm}$ with a spectrophotometer.

All the values were presented as mean \pm S.E. Differences between group means were assessed by a one-way analysis of variance (ANOVA) and post-hoc Duncan test used by SPSS/PC computer program (SPSS for Windows, 10.1 SPSS Inc., 1999). Results with $\mathrm{p}<0.05$ were considered statistically significant. The differences between the same two diet group with various flow were analyzed by Student's t-test (Microsoft Office pacet programe, 2007, $\mathrm{p}<0.05$ ).

\section{RESULTS}

\section{FW, CF, FCR and PER values}

FW, CF, FCR and PER values of rainbow trout are presented in Table IV. The highest final weigth was obtained in the $30 \mathrm{~g}$ propolis supplemented group $(\mathrm{p}<0.05)$, followed by the $10 \mathrm{~g}$ propolis supplemented group $(\mathrm{p}<0.05)$ and $60 \mathrm{mg}$ vitamin E supplemented group, while the lowest growth rate was obtained in the $\mathrm{C}$ group $(\mathrm{p}<0.05)$ for both flow rate treatments. CF and PER were not different among all diets groups for both flow rate treatments. The FCR improved in P10, P30 and $\mathrm{E} 60$ diets groups compared to $\mathrm{C}$ diet groups at $2.1 \mathrm{l} / \mathrm{min}$ flow rate. The FCR of E60 and P30 were found to be better than $\mathrm{C}$ and $\mathrm{P} 10$ diet groups at $0.9 \mathrm{l} / \mathrm{min}$ flow rate.

Accordig to Student t-test, it was obvious that FW, CF, FCR and PER values of fishes in all diets groups were negatively affected by low flow rate (Fig. 1).

\section{Serum Vitamin A, E and C concentrations}

Serum vitamin A, C and E concentrations of fish fed with the various experimental diets are presented in Table V. There was no significant difference in serum vitamin A concantrations of experimental diet groups for both flow rate treatments. Vitamin E levels in serum increased in E60 group compared to those of $\mathrm{C}$ group and propolis supplemented diet groups (P10, P30) for both flow rate treatments. Serum vitamin C concentration was significantly affected by $30 \mathrm{~g}$ propolis supplemented diet group, followed by the $10 \mathrm{~g}$ propolis supplemented diet
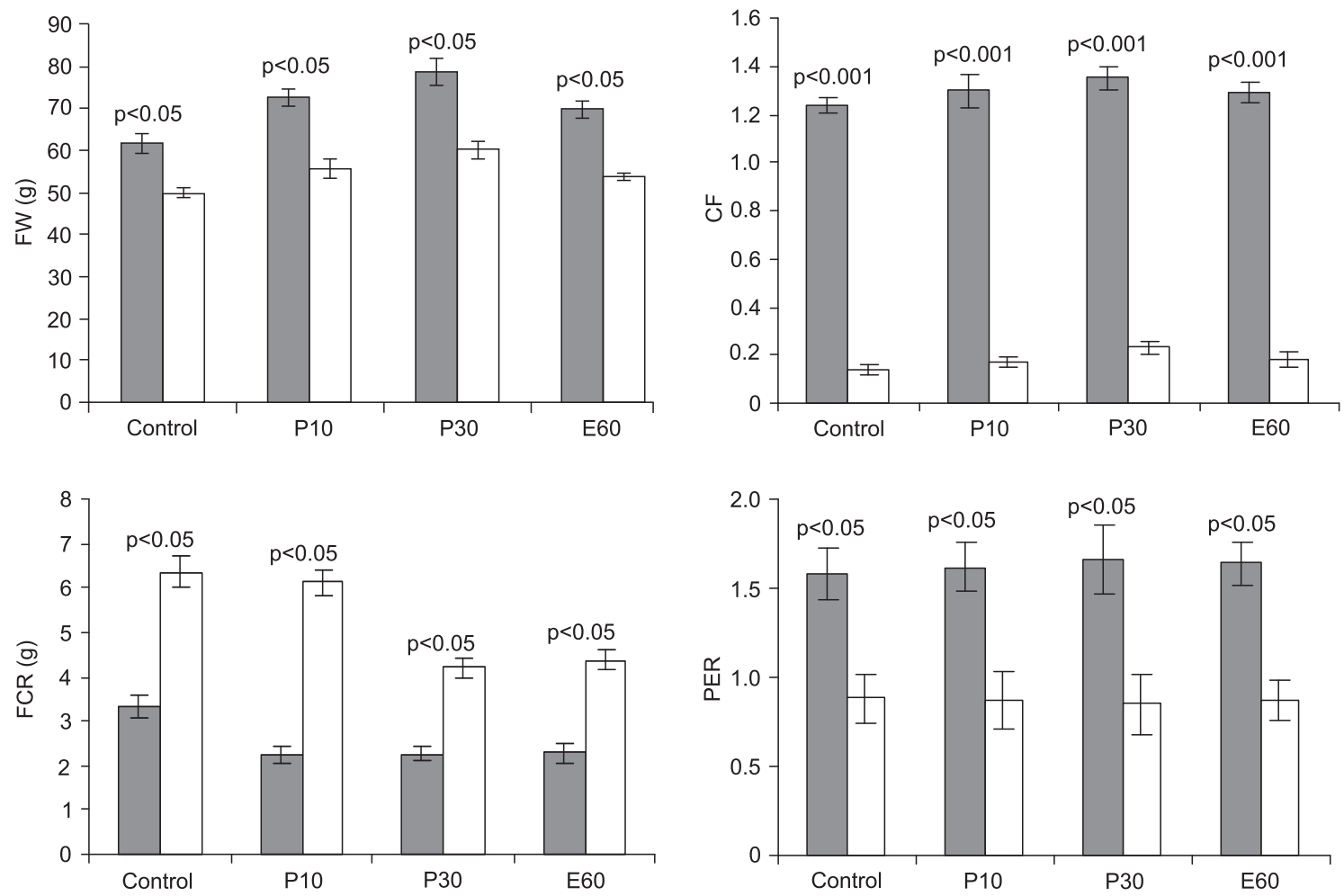

Figure 1. Effects of dietary supplementation with propolis and vitamin E on FW (final weigth), CF, FCR and PER in juvenile rainbow trout reared at two flow rate $(2.1$ and $0.9 \mathrm{l} / \mathrm{min})$ during the 12 week experiment. Data are presented as means $\pm \mathrm{SE}(\mathrm{n}=3$ replicates). A Student's t-test was used to test for different flow rate treatment effects $(p<0.05)$. $2.1 \mathrm{I} / \mathrm{min}, \square 0.9 \mathrm{I} / \mathrm{min}$. 
Table IV. Effects of dietary supplementation with propolis and vitamin E on FW, CF, FCR and PER in juvenile rainbow trout reared during at two different flow rate $(2.1$ and $0.9 / \mathrm{Imin})$.

\begin{tabular}{|c|c|c|c|c|c|}
\hline Experimental groups & $\mathrm{FR}^{1}\left(\mathrm{I} \mathrm{min}^{-1}\right)$ & $\mathrm{FW}^{2}(\mathrm{~g})$ & CF3 & FCR4 & PER5 \\
\hline K & 2.1 & $61.34 \pm 2.32^{c}$ & $1.24 \pm 0.03^{a}$ & $3.33 \pm 0.23^{b}$ & $1.58 \pm 0.15^{a}$ \\
\hline P10 & 2.1 & $72.38 \pm 2.12^{b}$ & $1.29 \pm 0.07^{a}$ & $2.25 \pm 0.21^{a}$ & $1.62 \pm 0.14^{a}$ \\
\hline P30 & 2.1 & $78.42 \pm 3.24{ }^{\mathrm{a}}$ & $1.35 \pm 0.05^{a}$ & $2.27 \pm 0.17 \mathrm{a}$ & $1.66 \pm 0.19 a$ \\
\hline E60 & 2.1 & $69.57 \pm 2.09^{b}$ & $1.29 \pm 0.03^{a}$ & $2.23 \pm 0.24^{\mathrm{a}}$ & $1.64 \pm 0.12^{a}$ \\
\hline K & 0.9 & $49.05 \pm 1.11^{c}$ & $0.14 \pm 0.02^{a}$ & $6.34 \pm 0.35^{b}$ & $0.88 \pm 0.14^{a}$ \\
\hline P10 & 0.9 & $55.42 \pm 2.34^{b}$ & $0.17 \pm 0.02^{a}$ & $6.12 \pm 0.27 \mathrm{~b}$ & $0.87 \pm 0.16^{a}$ \\
\hline P30 & 0.9 & $59.83 \pm 2.25{ }^{a}$ & $0.23 \pm 0.01^{a}$ & $4.21 \pm 0.21$ & $0.85 \pm 0.17^{a}$ \\
\hline E60 & 0.9 & $53.57 \pm 1.14 b^{c}$ & $0.20 \pm 0.03^{a}$ & $4.37 \pm 0.24^{a}$ & $0.87 \pm 0.11^{a}$ \\
\hline
\end{tabular}

${ }^{1}$ FR: Flow rate; 3FW: Final weight; 2Condition factor (CF): (W/L3) $\times 100 ; 3$ Feed conservation ratio (FCR): duration in days consumed feed/(final wt - initial wt); 4 Protein efficiency ratio (PER): (final wt - initial wt)/feed consumption $(\mathrm{g}) \times$ feed in the diet.

a-c Means in the same cloumn with different supscript are significantly (ANOVA, $p<0.05$ ).

Table V. Effects of dietary supplementation with propolis and vitamin E on serum vitamin A, E and C concentrations at two different flow rate (2.1 and $0.9 / 1 \mathrm{~min})$.

\begin{tabular}{ccccc}
\hline Experimental groups & Flow Rate $\left(\mathrm{min}^{-1}\right)$ & Serum Vit. A $(\mathrm{mg} / \mathrm{l})$ & Serum Vit. E (mg/l) & Serum Vit. C (mg/l) \\
\hline K & 2.1 & $0.71 \pm 0.05^{\mathrm{a}}$ & $10.95 \pm 1.32^{\mathrm{b}}$ & $6.72 \pm 1.17^{\mathrm{c}}$ \\
P10 & 2.1 & $0.69 \pm 0.04^{\mathrm{a}}$ & $10.77^{\mathrm{a}} \pm 1.43^{\mathrm{b}}$ & $10.14 \pm 1.11^{\mathrm{b}}$ \\
P30 & 2.1 & $0.72 \pm 0.07^{\mathrm{a}}$ & $11.09 \pm 1.27^{\mathrm{b}}$ & $16.25 \pm 2.25^{\mathrm{a}}$ \\
E60 & 2.1 & $0.75 \pm 0.08^{\mathrm{a}}$ & $22.42 \pm 1.44^{\mathrm{a}}$ & $7.19 \pm 1.34^{\mathrm{c}}$ \\
K & 0.9 & $0.33 \pm 0.02^{\mathrm{a}}$ & $2.11 \pm 0.82^{\mathrm{b}}$ & $2.49 \pm 0.54^{\mathrm{c}}$ \\
P10 & 0.9 & $0.37 \pm 0.01^{\mathrm{a}}$ & $3.87 \pm 0.74^{\mathrm{b}}$ & $4.34 \pm 0.36^{\mathrm{b}}$ \\
P30 & 0.9 & $0.35 \pm 0.01^{\mathrm{a}}$ & $2.09 \pm 0.31^{\mathrm{b}}$ & $7.28 \pm 0.42^{\mathrm{a}}$ \\
E60 & 0.9 & $0.37 \pm 0.01^{\mathrm{a}}$ & $8.05 \pm 1.54^{\mathrm{a}}$ & $2.92^{\mathrm{a}} \pm 0.44^{\mathrm{c}}$ \\
\hline
\end{tabular}

a-c Means in the same cloumn with different supscript are significantly (ANOVA, $p<0.05)$.

group as well as serum vitamin $\mathrm{C}$ concentration was similarly affected in $\mathrm{C}$ and $\mathrm{E} 60$ diet groups for both flow rate treatments (Tab. IV).

The results of Student's t-test showed that vitamin A, E and $\mathrm{C}$ concentrations in serum were negatively affected by low flow rates in all diets groups (Fig. 2).

\section{Serum MDA levels and Plasma SOD activity}

Shown in Table VI, serum MDA levels and plasma SOD enzyme activites of fish fed with the various experimental diets at 2.1 and $0.9 \mathrm{l} / \mathrm{min}$ flow rate treatments. The results of one-way ANOVA test showed that serum MDA levels of fish were positively affected by dietary supplementation of propolis and vitamin E. Serum MDA level was significantly affected by $60 \mathrm{mg}$ vitamin E supplemented diet group, followed by the $30 \mathrm{~g}$ propolis supplemented diet group for both flow rate treatments (Tab. VI). Besides, serum MDA level of C and P10 diets groups was found significantly higher than P30 and E60 diet groups. However, Serum MDA levels were similarly affected in C, and P10 diet groups for both flow rate treatments (Tab. VI). Plasma SOD activity of C, P10, P30 and E60 groups were found as $13.89,12.02,12.11,8.13 \mathrm{U} / \mathrm{ml}$, respectively at $2.1 \mathrm{l} / \mathrm{min}$ and plasma SOD activity of C, P10, P30 and E60 groups were found as $4.4,4.3,4.2,4.3 \mathrm{U} / \mathrm{ml}$, respectively at $0.9 \mathrm{l} / \mathrm{min}$ flow rate. Plasma SOD activity significantly decreased in the E60 group compared to other groups at $2.1 \mathrm{l} / \mathrm{min}$ flow rate. But plasma SOD activity was not different among all diet groups at 0.9 flow rate (Tab. VI).

The results of Student's t-test showed that serum MDA levels of fishes exposed to $0.9 \mathrm{l} / \mathrm{min}$ flow rate in all diet groups significantly increased while plasma SOD enzym activity of fishes exposed to $0.9 \mathrm{l} / \mathrm{min}$ flow rate significantly decreased in all diet groups compared to unstressed groups (Fig. 3).

\section{DISCUSSION}

Hypoxia has been recognized as one of the main mass mortality factors in aquatic organism populations (PAERL et al. 1998). Fish exposed to hypoxic conditions also have reduced developmental rates (TAYLOR \& Miller 2001). Stress leads to generation of free radicals, such as $\mathrm{O}_{2}{ }^{-}$and $\mathrm{HO}$. These free radicals can damage cell membranes by inducing lipid peroxidation of polyunsaturated fatty acids in the cell membrane (SORG 2004). 

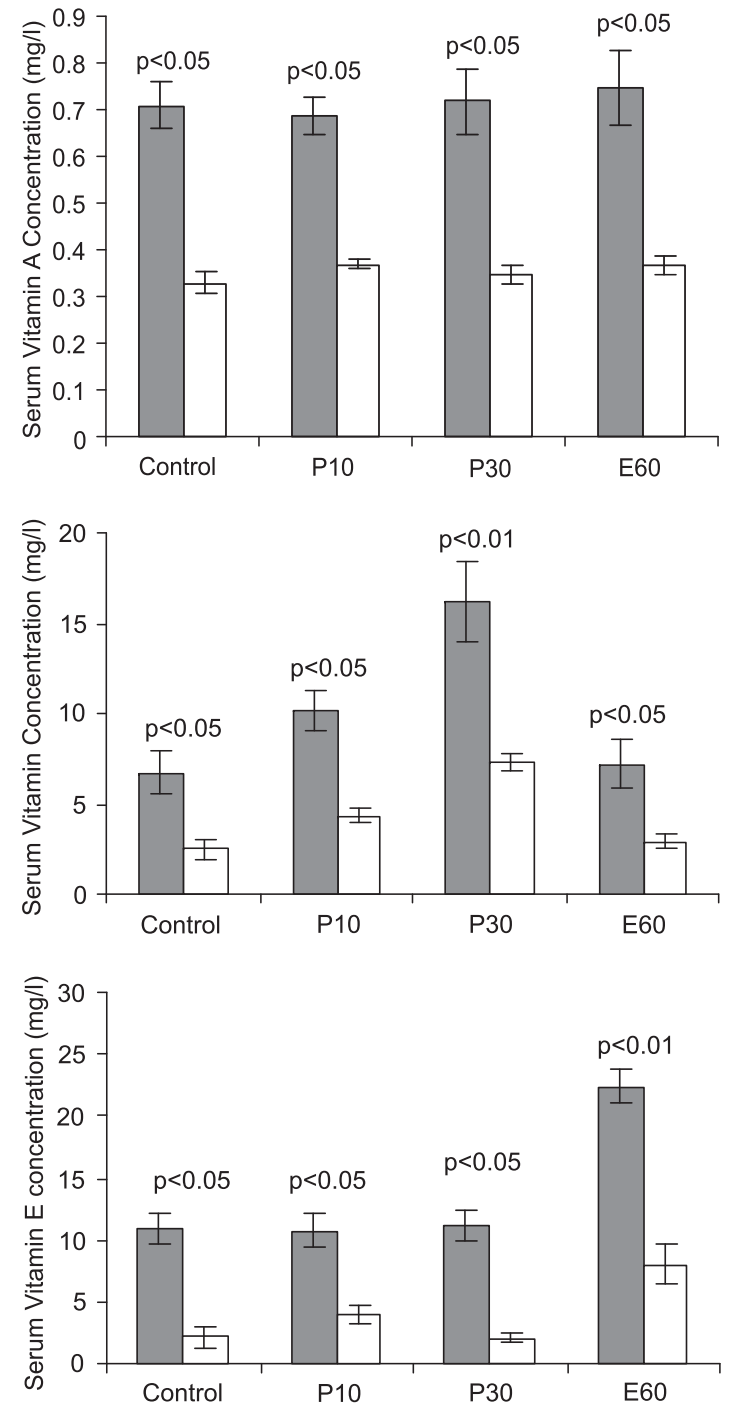

Figure 2. Effects of dietary supplementation with propolis and vitamin $\mathrm{E}$ on tissues (muscle, kidney and liver) vitamin $\mathrm{A}, \mathrm{C}$ and $\mathrm{E}$ concentrations in juvenile rainbow trout reared at two flow rate treatment (2.1 and 0.9/I min) during the 12 week experiment. Data are presented as means $\pm S E(n=3$ replicates). A Student's ttest was used to test for different flow rate treatment effects ( $p>$ 0.05). $\square 2.1 \mathrm{I} / \mathrm{min}, \square 0.9 \mathrm{I} / \mathrm{min}$.

Salmonid tissues are characterized by high concentrations of polyunsaturated fatty acids compared with most mammalian tissues, and fish may, therefore, be particularly susceptible to lipid peroxidative cellular damage (GüLçıN et al. 2009). There follows a consequent loss of cellular homeostasis and membrane integrity, which subsequently leads to cellular degradation and death. Antioxidant matters added to diet in order to support the protective activity of the antioxidant defense sys-
Table VI. Effects of dietary supplementation with propolis and vitamin $\mathrm{E}$ on plasma SOD activity and serum MDA levels at two different flow rate (2.1 and $0.9 / \mathrm{l} \mathrm{min}$ ).

\begin{tabular}{|c|c|c|c|}
\hline $\begin{array}{l}\text { Experimental } \\
\text { groups }\end{array}$ & $\begin{array}{l}\text { Flow Rate } \\
\left(1 \mathrm{~min}^{-1}\right)\end{array}$ & $\begin{array}{c}\text { Serum MDA level } \\
(\mathrm{nmo} / \mathrm{ml})\end{array}$ & $\begin{array}{c}\text { Plasma SOD } \\
\text { Activity }(\mathrm{U} / \mathrm{ml}) \\
\end{array}$ \\
\hline K & 2.1 & $3.26 \pm 0.89 a$ & $13.89 \pm 1.17$ \\
\hline P10 & 2.1 & $3.17 \pm 0.92^{a}$ & $12.02 \pm 1.09$ \\
\hline P30 & 2.1 & $2.12 \pm 0.75^{b}$ & $12.11 \pm 1.12$ \\
\hline E60 & 2.1 & $0.87 \pm 0.27^{c}$ & $8.13 \pm 1.17^{b}$ \\
\hline K & 0.9 & $13.23 \pm 1.45^{a}$ & $4.4 \pm 1.21^{\mathrm{a}}$ \\
\hline P10 & 0.9 & $12.29 \pm 1.12^{a}$ & $4.3 \pm 1.17^{a}$ \\
\hline P30 & 0.9 & $9.95 \pm 1.15^{b}$ & $4.2 \pm 1.13^{a}$ \\
\hline E60 & 0.9 & $6.14 \pm 1.12^{c}$ & $4.3 \pm 1.20^{a}$ \\
\hline
\end{tabular}

a-c Means in the same cloumn with different supscript are significantly (ANOVA, $\mathrm{p}<0.05$ ).

tems have a vital role (SEVEN et al. 2010). It is known that vitamin E show antioxidant characteristics to the oxidants in the cell membrane and another compound in the structure of propolis, caffeic acid phenethyl ester (CAPE), blocks the production of reactive oxygen types (Seven et al. 2010, Hosnuter et al. 2004).

Vitamin E ( $\alpha$-tocopherol) function as biological antioxidants to protect cellular macromolecules (DNA, protein, lipids) and other antioxidant molecules from uncontrolled oxidation by free radicals during normal metabolism or under the conditions of oxidative challenge such as infection, stress, and pollution (HuANg \& Huang 2004, RufF et al. 2002). Survival of fish fed the vitamin E supplemented diets was higher in general. Vitamin E functions as a lipid-soluble antioxidant protecting biological membranes and lipoproteins against oxidation, and it has been demonstrated to be an essential dietary nutrient for all fish studied (NRC 1993). High vitamin E content in tissues would inhibit tissue lipid peroxidation (Murata \& Yamauchi 1989, Frigg et al. 1990, Sau et al. 2004). Similar trends have been reported in rainbow trout (FrIGG et al. 1990), turbot (STEPHAN et al. 1995), sea bass (GATTA et al. 2000), and Atlantic halibut (RufF et al. 2002). These reports indicated that the higher vitamin E consumption by the fish, the greater vitamin E concentrations in fish tissue, thus resulted in lower lipid peroxidation. They also determined that both liver and muscle vitamin $\mathrm{E}$ contents increased when dietary vitamin $\mathrm{E}$ level increased and lipid peroxidation in tilapia tissues was significantly influenced by the dietary vitamin E level. Results from the our study are in consistent with previous studies where the dietary supplementation of vitamin $\mathrm{E}$ at elevated levels increased the concentration of tocopherol and decreased lipid peroxidation in serum of fish.

In our study, it was observed that serum MDA levels of fish were positively affected by dietary supplementation of 60 $\mathrm{mg}$ vitamin $\mathrm{E}$, followed by dietary supplementation of $30 \mathrm{~g}$ propolis in both stressed and unstressed fish. According to the 

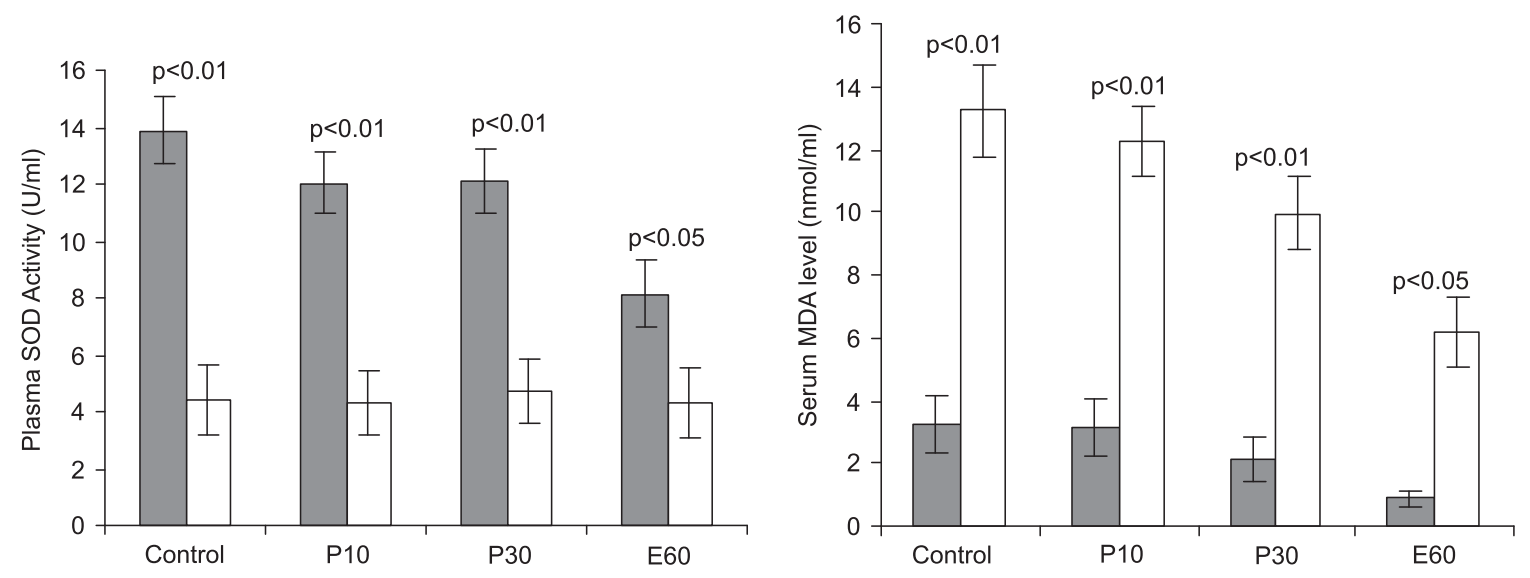

Figure 3. Effects of dietary supplementation with propolis and vitamin E on plasma SOD activity and serum MDA level of juvenile rainbow trout reared at two flow rate $(2.1$ and $0.9 / 1 \mathrm{~min})$ during the 12 weeks. Data are presented as means $\pm S E(n=3$ replicates). A Student's t-test was used to test for different flow rate treatment effects $(p<0.05)$. $\square 2.1 \mathrm{I} / \mathrm{min}, \square 0.9 \mathrm{l} / \mathrm{min}$.

findings of this study, it was shown that propolis had possitive effect on oxidative stress and decreased MDA levels in plasma in accordance with other research. As shown in previous studies (Ates et al. 2006, Tatli Seven et al. 2009), MDA levels increased when the lipid peroxidation was formed. According to current study, it was thought that propolis addition was effective in decreasing the adverse effect of lipid peroxidation and would show similar antioxidant effects as Vitamin E (ОкоNENKO et al. 2006).

KashKooli et al. (2001) reported that dietary propolis supplementation unaffected growth performance of propolis supplementation in rainbow trout. Azza \& El-Rahman (2009) observed that propolis supplementation caused significantly effects on growth performance in Nile tilapia, Oreochromis niloticus (Linnaeus, 1758). In our study, two antioxidants (vitamin E and propolis) significantly decreased negative effects resulting from low flow stress on FCR. But propolis and vitamin E suplamentation did not effect on CF and PER in stressed and unstressed groups. These different effects of propolis may be due to the dose and different fish species used or relate to the study condition (stressed and unstressed). Propolis supplementation is used in poultry diets (Tatli Seven 2008). Tatli Seven (2008), Tatli Seven \& Seven (2008), Tatli Seven et al. (2009), reported that dietary propolis supplementation increased FCR in broiler and laying hens under heat stress. Similar findigs was determined our study. Moreover, it was observed that propolis supplementations (10 and $30 \mathrm{~g} \mathrm{~kg}^{-1}$ ) in diet protected vitamin $\mathrm{C}$ concentrations in tissues. The similar effects of propolis on vitamin C in stress conditions was reported by TATLI SEVEN (2008).

Obviously, SOD is an important enzyme family in living cells for maintaining normal physiological conditions and coping with stress (CHEN \& PAN 1996). Antioxidant defenses in fish are depend on feeding behavior and nutritional factors. In addition, environmental conditions and seasonal changes have been reported to influence antioxidant defenses of fish (Martínez-Álvarez et al. 2005). Palace et al. (1993) observed that SOD activity in the tissues of rainbow trout fed with $\alpha$-tocopherol deficient diet increased. Similar results were also reported in hybrid tilapia (HuAng \& Huang 2004) fresh water pawn (DANDAPAT et al. 2000). In our study was observed that the addition of $60 \mathrm{mg} / \mathrm{kg}$ vitamin E significantly decreased the plasma SOD activity compare to the other groups at optimal flow rate, but significant differences were not observed the plasma SOD activities of fish exposed to low flow rate treatment.

SOD activity of $60 \mathrm{mg}$ vitamin $\mathrm{E}$ added group was lower compared to other groups at $2.1 \mathrm{l} / \mathrm{min}$ flow rate treatment (optimal flow rate). However, some studies have reported a decrease (WoHAIEв \& Godin 1987, OzKaYa et al. 2002) while others have reported an increase in SOD activity in case of lipid peroxidation such as SOD in lipid peroxidation (HUANG et al. 1999, Aliciguzel et al. 2003). In a study where the effect of CAPE were investigated on antioxidant enzym activity in rats exposed to cold stres. It was determined that cold stress significantly decreased SOD antioxidant enzym activity (ATEs et al. 2006). Similary, in our study, it was determined that the plasma SOD activity significantly decreased in juvenile rainbow trout exposed to low flow rate treatment.

In conclusion, dietary supplementations (vitamin $\mathrm{E}$ and propolis) of juvenile rainbow trout with antioxidants alleviated the flow stress-induced oxidative damages. Two antioxidants (vitamin $\mathrm{E}$ and propolis) significantly decreased the negative effects of flow stress on FCR. Moreover, propolis supplementation (30 g/kg diet) was more effective on FCR, vitamin C concentration and repressive effect of serum MDA level, while vitamin E supplementation $(60 \mathrm{mg} / \mathrm{kg}$ diet) was more effective in preventing lipid peroxidation in serum. Additionally, vitamin E supplementation also decreased the SOD activity level in plasma and improved vitamin E concentration in 
serum at 2.1 flow rate. Propolis can be used an antioxidant in rainbow trout as Vitamin E. Using $30 \mathrm{~g} / \mathrm{kg}$ of propolis supplementation in juvenile rainbow trout diets may relieve the adverse effect of lipid peroxidation on the antioxidant defense system. To summarize in our study demostrated that long term low flow rate caused oxidative stress in juvenile rainbow trout. As results of the oxidative stress; (I) FW, CF, FCR and PER values decreased (II) A, C ve $\mathrm{E}$ vitamin concantrations decreased in serum (III) MDA level increased in serum (IV) SOD enzym activity decreased in plasma. Further studies should be carried out to determine the effect of propolis on protection of oxidative-antioxidative balance mechanism of aquatic animals under various stress factors.

\section{LITERATURE CITED}

Aliciguzel, Y.; I. Ozen; M. Aslan; U. Karayalcin. 2003. Activities of xanthine oxidoreductase and antioxidant enzymes in different tissues of diabetic rats. Journal of Laboratory and Clinical Medicine 142: 172-177.

AOAC. 1990. Official Methods of Analysis. Washington. D.C., Academy Press, Association of Agricultural, Association of Official Analytical Chemists.

Andrade, J.A.; A.E. Ono; G.C. Menezes; E.M. Brasil; R. Roubach; E.C. Urbinati; M. Tavares-Dias; J.L. Marcon \& E.G. Affonso. 2007. Influence of diets supplemented with vitamins $C$ and E on pirarucu (Arapaima gigas) blood parameters. Comparative Biochemistry and Physiology 146: 576-580.

Atamanalp, M. \& A. Bayir. 2003. The effects of subletal doses a disinfectant (Malachite Green) on blood parameters of rainbow trout (Oncorhynchus mykiss). Gazi University Journal of Science 23 (3): 177-187.

Ates, B.; M.I. Dogru; M. Gul; A. Erdogan; I. Yilmaz; M. YurekLi \& M. EsREfoglu. 2006. Protective role of caffeic acid phenethyl ester in the liver of rats exposed to cold stress. Fundamental \& Clinical Pharmacology 20: 283-289.

Azza, M.M. \& A. El-Rhman. 2009. Antagonism of Aeromonas hydrophila by propolis and its effect on the performance of Nile tilapia, Oreochromis niloticus. Fish and Shellfish Immunology 27: 454-459.

Blonska, M.; J. Bronikowska; G. Pietsz; Z.P. Czuba; S. Scheller \& W. Krol. 2004. Effects of ethanol extract of propolis (EEP) and its flavones on inducible gene expression in J774A.1 makrophages. Journal of Ethnopharmacology 91: 25-30.

Chen, C.N. \& S.M. Pan. 1996. Assay of superoxide dismutase activity by combining electrophoresis and densitometry. Botanical Bulletin of Academia Sinica 37: 107-111.

Choi, S.W.; I.F.F. Benzic; A.R. Collins; B.M. Hannigan \& J.J. Strain. 2004. Vitamin C and E: acut interactive effects on biomarkers of antioxidant defance and oxidative stress. Mutation Research 551 (1-2): 109-117.

CONTE, F.S. 2004. Stress and the welfare of cultured fish. Applied Animal Behaviour Science 86: 205-223.
Dandapat, J.; G.B.N. Chainy \& K.J. Rao. 2000. Dietary vitamin-E modulates antioxidant defence system in giant freshwater prawn, Macrobrachium rosenbergii. Comparative Biochemistry and Physiology 127: 101-115.

FANG, Y.Z.; S. YANG \& G. WU. 2002. Free radicals, antioxidants and nutrition. Nutrition 18: 872-879.

Frigg, M.; A.L. Prabucki \& E.U. Ruhedl. 1990. Effects of dietary vitamin E levels on oxidative stability of trout fillets. Aquaculture 84: 145-158.

Gabryelak, T.; M. Piatrowska; W. Leyko \& G. Peres. 1983. Seasonal variation in the activities of peroxide metabolism enzymes in erythrocytes of freshwater fish species. Comparative Biochemistry and Physiology 75: 383-385.

Gatta, P.P.; M. Pirini; S. Testi; G. Vignola \& P.G. Monetti. 2000. The influence of different levels of dietary vitamin $\mathrm{E}$ on sea bass, Dicentrarchus labrax flesh quality. Aquaculture Nutrition 6: 47-52.

Gülçin, I.; S. Beydemir; O. Hisar; E. Köksal \& R.J. Reiter. 2009. Melatonin administration increases antioxidant enzymes activities and reduces lipid peroxidation in the rainbow trout (Oncorhynchus mykiss, Walbaum) erythrocytes. Turkish Journal of Veterinary and Animal Sciences 33 (3): 241245 .

Henrique, M.M.F.; E.F. Gomes; M.F. Gouillou-Coustans; A. OlivaTeles \& S.J. Davies. 1998. Influence of supplementation of practical diets with vitamin $C$ on growth and response to hypoxic stress of seabream, Sparus Aurata. Aquaculture 161 (1-4): 415-426.

Hidalgo, M.C.; A. Exposito; J.M. Palma \& M. Higuera. 2002. Oxidative stress generated by dietary Zn-deficiency: studies in rainbow trout (Oncorhynchus mykiss). The International Journal of Biochemistry \& Cell Biology 34: 183-193.

Hosnuter, M.; A. Gurel; O. Babuccu; F. Armutcu; E. Kargi \& A. ISIKDEMIR. 2004. The effect of CAPE on lipid peroxidation and nitric oxide levels in the plasma of rats following thermal injury. Burns 30: 121-125.

Huang, C.H. \& S.L. Huang. 2004. Effect of dietary vitamin E on growth, tissue lipid peroxidation and liver glutathione level of juvenile hybrid tilapia, Oreocromis niloticus x O. aureus fed oxidized oil. Aquaculture 237: 381-389.

Huang, W.C.; S.W. Juang; I.M. Liu; T.C. Chi \& J.T. Cheng. 1999. Changes of superoxide dismutase gene expression and activity in the brain of streptozotocin-induced diabetic rats. Neuroscience Letters 5: 25-28.

JIA, X.; H. ZHANG \& X. Liu. 2010. Low levels of cadmium exposure induce DNA damage and oxidative stress in the liver of Oujiang colored common carp Cyprinus carpio. Fish Physiology and Biochemistry 31 (1): 97-103.

Karatepe, M. 2004. Simultaneous determination of ascorbic acid and free malondialdehyde in human serum by HPLC/UV. LCGC North America 32 (4): 362-365.

Kashrooli, O.B.; E.E. Dorcheh; N. Mahboobi-Soofiani \& A. Samie. 2001. Long-term effects of propolis on serum biochemical 
parameters of rainbow trout (Oncorhynchusmykiss). Ecotoxicology and Environmental Safety 74: 315-318.

Kimoto, N.; M. Hirose; M. Kawabe; T. Satoh; H. Miyataka \& T. SHIRAI. 1999. Post-initiation effects of a super critical extract of propolis in a rat two-stage carcinogenesis model in female F344 rats. Cancer Letters 147: 221-227.

Lopez-Torres, M.; R. Perez-Campos; S. Cadenas; C. Rojas \& G. Barja. 1993. A comparative study of free radicals in vertebrates-II. Non-enzymatic antioxidants and oxidative stress. Comparative Biochemistry and Physiology 105: 757-763.

LushchaK, V.I. \& T.V. BAgnyukova. 2006. Effects of different environmental oxygen levels on free radical processes in fish. Comparative Biochemistry and Physiology 44: 283289.

Markovic, M.D.; R.V. Zikic; A.S. Stajn; B.I. Ognjanovic; S.Z. Pavlovic; R. Radojicic \& Z.S. SAICIC. 2002. Some blood parameters and antioxidant defense enzyme activities in the liver of carps (Cyprinus carpio L.) under acute hypoxic conditions. Kragujevac Journal of Science 24: 111-120.

Martínez-Álvarez, R.M.; A.E. Morales \& A. Sanz. 2005. Antioxidant defenses in fish: Biotic and abiotic factors. Reviews in Fish Biology and Fisheries 15 (1-2): 75-88.

McCord, J.M. \& I. Fr1Dov1CH. 1969. Superoxide dismutase: an enzymatic function for erythrocuprein. Journal of Biological Chemistry 244: 6049-6055.

Miller, K.W.; N.A. LorR; C.S. YANG. 1984. Simultaneous determination of plasma retinol, tocopherol, lycopene, alphacarotene, and beta-carotene by high-performance liquid chromatography. Analytical Biochemistry 138: 340-345.

Murata, H. \& K. Yamauchi. 1989. Relationship between 2thiobarbituric acid values of some tissues from cultured red sea bream and its dietary $\alpha$-tocopherol levels. Nip Suis Gakkaishi 55: 1435-1439.

NRC, 1993. Nutrient requirements of fish. Washington, D.C., National Academy of Sciences, National Research Council.

OKonenko, L.B.; B.B. Aidarkhanov; A.A. RaKhmetova; SSH. ZhaKisheva $\&$ ZHS. IKSYMbaEVA. 2006. Vitamin $\mathrm{E}$ and propolis as antioxidants after excessive administration of polyunsaturated fatty acids. Fundamental \& Clinical Pharmacology 20: 283-289.

Ozkaya, Y.G.; A. Agar \& P. Yargicioglu. 2002. The effect of exercise on brain antioxidant status of diabetes. Diabetes \& Metabolism 28: 377-384.

Paerl, H.W.; J.L. Pinckney; J.M. Fear \& B.L. Peierls. 1998. Ecosystem responses to internal and watershed organic matter loading: consequences for hypoxia in the eutrophying Neuse River Estuary, North Carolina, USA. Marine Ecology Progress Series 166: 17-25.

Palace, V.P.; H.S. MajewsKi \& J.F. KLaverKamp. 1993. Interactions among antioxidant defences in liver of rainbow trout (Oncorhynchus mykiss) exposed to cadmium. Canadian Journal of Fisheries and Aquatic Sciences 50: 156-162.

PrytzyK, E.; A.P. Dantas; K. SalomaO; A.S. Pereira; V.S. Bankova; S.L. de Castro \& F.R. Neto. 2003. Flavonoids and trypanocidal activity of Bulgarian propolis. Journal of Ethnopharmacology 88: 189-193.

Puangkaew, J.; V. Kiron; S. Satoh \& T. Watanabe. 2005. Antioxidant defense of rainbow trout (Oncorhynchus mykiss) in relation to dietary n-3 highly unsaturated fatty acids and vitamin $\mathrm{E}$ contents. Comparative Biochemistry and Physiology 140: 187-196.

Quiles, J.; J. Huertas; M. Batine; J. Mataix \& C. Tortosa. 2002. Antioxidant nutrients and adriamycin toxicity. Toxicology 180: 79-95.

RufF, N.; R.D. FItzGerald; T.F. Cross \& J.P. KerRY. 2002. Fillet shelflife of Atlantic halibut Hippoglossus hippoglossus L. fed elevated levels of $\alpha$-tocopheryl acetate. Aquaculture Research 33: 1059-1071.

SaU, S.K.; B.N. Paul; S.N. Mohanta \& S.N. Mohanty. 2004. Dietary vitamin $\mathrm{E}$ requirement, fish performance and carcass composition of rohu (Labeo Rohita) fry. Aquaculture 240: 359-368.

Selamoglu Talas, Z.; I. Orun; I. Ozdemir; K. Erdogan; A. Alkan \& I. YILMAZ. 2008. Antioxidative role of selenium against the toxic effect of heavy metals $(\mathrm{Cd}+2, \mathrm{Cr}+3)$ on liver of rainbow trout (Oncorhynchus mykiss, Walbaum 1792). Fish Physiology and Biochemistry 34: 217-222.

Seven, I.; T. Aksu \& P. Tatli Seven. 2010. The effects of propolis on biochemical parameters and activity of antioxidant enzymes in broilers exposed to lead-induced oxidative stress. Asian-Australasian Journal of Animal Sciences 23 (11): 1482-1489.

Sorg, O. 2004. Oxidative stress: a theoretical model or a biological reality? Comptes Rendus Biologies 327: 649-662.

Stephan G.; J. Guillaume \& F. Lamour. 1995. Lipid peroxidation in turbot (Scophthalmus maximus) tissue: effect of dietary vitamin E and dietary n-6 or n-3 polyunsaturated fatty acid. Aquaculture 130: 251-268.

TAlas, Z.S. \& M.F. GulHan. 2009. Effects of various propolis concentrationson biochemical and hematological parameters of rainbow trout (Oncorhynchus mykiss). Ecotoxic Environ Saffety 72 (7): 1994-1998.

Tatli Seven, P. 2008. The effects of dietary Turkish propolis and vitamin $\mathrm{C}$ on performance, digestibility, egg production and egg quality in laying hens under different environmental temperatures. Asian-Australasian Journal of Animal Sciences 21: 1164-1170.

Tatui Seven, P. \& I. Seven. 2008. Effect of dietary Turkish propolis as alternative to antibiotic on performance and digestibility in broilers exposed to heat. Journal of Applied Animal Research 34: 193-196.

Tatli Seven, P.; S. Yilmaz; I. Seven; I.H. Cerci; M.A. Azman \& M. YILMAZ. 2009. Effects of propolis on selected blood indicators and antioxidant enzyme activities in broilers under heat stress. Acta Veterinaria Brno 78: 75-83.

TAYLOR, J.C. \& J.M. Miller. 2001. Physiological performance of juvenile southern flounder, Paralichthys lethostigma (Jordan and Gilbert, 1884), in chronic and episodic hypoxia. Journal 
of Experimental Marine Biology and Ecology 258: 195214.

Tuna Kelestemur, G. \& Y. Ozdemir. 2010. Effect of low oxygen level on some blood parameter levels of fry rainbow trout (Oncorhynchus mykiss, W. 1792). Journal of Fisheries Sciences 4 (4): 310-317.

WANG, B.J.; Y.H. Lien \& Z.R. YU. 2004. Supercritical fluid extractive fractionation: study of the antioxidant activities of propolis. Food Chemistry 86: 237-243.

Wejil, N.I.; F.J. Cleton \& S. Osanto. 1997. Free radicals and antioksidants in chemotheraphy induced toxicity. Cancer Treatment Reviews 23: 209-240.

Wohaieb, S.A. \& D.V. God1N. 1987. Alterations in free radical tissue-defence mechanisms in streptozocin-induced diabetes in rat. Effects of insulin treatment. Diabetes 36: 10141018. doi:10.2337/diabetes.36.9.1014

Submitted: 16.X.2011; Accepted: 01.III.2012.

Editorial responsibility: Walter A. Boeger 